\title{
Characterization of the angiotensin-converting enzyme inhibitory activity of fermented milks produced with Lactobacillus casei
}

\author{
Changkun Li, ${ }^{*} \dagger$ Lai-Yu Kwok, ${ }^{*} \dagger$ Zhihui Mi, ${ }^{\dagger} \dagger$ Jinnima Bala, ${ }^{*}$ Jiangang Xue, ${ }^{*}$ Jie Yang, ${ }^{*}$ Yuzhu Ma, ${ }^{\dagger} \dagger$ \\ Heping Zhang, ${ }^{*} \dagger^{1}$ and Yongfu Chen ${ }^{*}{ }^{1}$ \\ *Key Laboratory of Dairy Biotechnology and Engineering, Ministry of Education P. R. C., and \\ †Key Laboratory of Dairy Products Processing, Ministry of Agriculture P. R. C., Inner Mongolia Agricultural University, Huhhot 010018, P. R. China
}

\section{ABSTRACT}

Our study assayed angiotensin-converting enzyme (ACE) inhibitory activity and fermentation characteristics of 41 food-originated Lactobacillus casei strains in fermented milk production. Twenty-two of the tested strains produced fermented milks with a high ACE inhibitory activity of over 60\%. Two strains (IMAU10408 and IMAU20411) expressing the highest ACE inhibitory activity were selected for further characterization. The heat stability (pasteurization at $63^{\circ} \mathrm{C}$ for $30 \mathrm{~min}$, $75^{\circ} \mathrm{C}$ for $25 \mathrm{~s}$, and $85^{\circ} \mathrm{C}$ for $20 \mathrm{~s}$ ) and resistance to gastrointestinal proteases (pepsin, trypsinase, and sequential pepsin/trypsinase treatments) of the $\mathrm{ACE}$ inhibitory activity in the fermented milks produced with IMAU10408 and IMAU20411 were determined. Interestingly, such activity increased significantly after the heat or protease treatment. Because of the shorter milk coagulation time of $L$. casei IMAU20411 (vs. IMAU10408), it was selected for optimization experiments for ACE inhibitory activity production. Our results show that fermentation temperature of $37^{\circ} \mathrm{C}$, inoculum density of $1 \times 10^{6} \mathrm{cfu} / \mathrm{g}$, and fermentation time of $12 \mathrm{~h}$ were optimal for maximizing ACE inhibitory activity. Finally, the metabolite profiles of $\mathrm{L}$. $\mathrm{Ca}$ sei IMAU20411 after 2 and $42 \mathrm{~h}$ of milk fermentation were analyzed by ultra-HPLC electron spray ionization coupled with time-of-flight mass spectrometry. Nine differential abundant metabolites were identified, and 2 of them showed a strong and positive correlation with fermented milk ACE inhibitory activity. To conclude, we have identified a novel ACE inhibitory L. casei strain, which has potential for use as a probiotic in fermented milk production.

Key words: Lactobacillus casei, angiotensin-converting enzyme, fermented milk, peptide

\footnotetext{
Received April 1, 2017.

Accepted August 10, 2017.

${ }^{1}$ Corresponding authors: nmgyfchen@126.com

hepingdd@vip.sina.com

and
}

\section{INTRODUCTION}

Hypertension is a common medical condition that affects about 10 to $20 \%$ of the adult population and 40 to $50 \%$ of people aged 50 yr or older (Karakurt and Kaşikçi, 2012). It may lead to stroke, coronary heart disease, kidney dysfunction, disability, and death (LópezFandiño et al., 2006). Angiotensin-converting enzyme (ACE, EC 3.4.15.1) is a peptidyl dipeptide hydrolase that plays an important physiological role in regulating blood pressure (Shu et al., 2015). The mechanism of action of ACE is based on cleaving the C-terminal dipeptide of angiotensin I (Asn-Arg-Val-Tyr-Ile-HisPro-Phe-His-Leu) to release the strong vasoconstrictor angiotensin II (Asn-Arg-Val-Tyr-Ile-His-Pro-Phe) that participates in the renin angiotensin system. This in turn leads to an increase in blood pressure (Skeggs et al., 1956). Furthermore, ACE also inactivates bradykinin, an important vasodilator, and thus elevates blood pressure. Several ACE chemical inhibitors, such as captopril, enalapril, lisinopril, and temocapril, are currently used for hypertension management. However, a long-term use of these drugs may cause deleterious side effects; thus, the search for natural ACE inhibitors for safe and economical use is highly necessary and meaningful (Coates, 2003).

During the lactic acid bacteria (LAB) milk fermentation process, milk proteins are hydrolyzed into long oligopeptides by cell-wall-associated proteinases. These oligopeptides will then be transported into the cells and further broken down by intracellular peptidases into various peptides (Nielsen et al., 2009). Several ACE inhibitory peptides have been isolated from fermented milks produced with different LAB, such as Lactobacillus helveticus (Kilpi et al., 2007; Liang and Chen, 2009), Lactococcus lactis (Rodríguez-Figueroa et al., 2012), Lactobacillus casei (Gonzalez-Gonzalez et al., 2011; Domínguez-González et al., 2014), Lactococcus acidophilus, and L. jensenii (Pihlanto et al., 2010). Lactobacillus casei is a commonly used starter and probiotic bacterium for production of fermented milk and other 
fermented foods. Some L. casei strains exhibit ACE inhibitory activity. For example, Domínguez-González et al. (2014) observed an effective ACE inhibitory activity of the well-known $L$. casei Shirota strain when it was cocultured with the starter bacterium Streptococcus thermophilus. Gonzalez-Gonzalez et al. (2011) observed a high ACE inhibitory activity in skim milk fermented with the L. casei Shirota YIT 9029 strain. Similarly, our research team previously produced Cheddar cheese with a strong ACE inhibitory activity with a koumissoriginated strain, L. casei Zhang (Wang et al., 2010).

The best characterized ACE inhibitory materials are the milk protein-derived peptides. Some of these peptides have been shown to be ACE inhibitory in vitro (Bütikofer et al., 2008; Escudero et al., 2014) and antihypertensive in vivo (Vermeirssen et al., 2005; Fitzgerald and Murray, 2006). The first characterized ACE inhibitory peptides, Val-Pro-Pro (VPP) and IlePro-Pro (IPP), were identified in milks fermented with L. helveticus (Nakamura et al., 1995), followed by the discovery of other milk-derived peptides having the same activity. For instance, the antihypertensive peptide (Ser-Lys-Val-Tyr-Pro) was isolated from fermented milk produced with the strains Streptococcus salivarius ssp. thermophilus and Lactococcus lactis biovar diacetylactis (Ashar and Chand, 2004). Quirós et al. (2009) identified 2 other bioactive peptides (Leu-His-Leu-ProLeu-Pro and Leu-Val-Tyr-Pro-Phe-Pro-Gly-Pro-IlePro-Asn-Ser-Leu-Pro-Gln-Asn-Ile-Pro-Pro) in Enterococcus faecalis fermented milk. These peptides were found to be antihypertensive after acute and long-term oral administration to spontaneously hypertensive rats. Although all these reported bioactive peptides are milk originated, their AA sequences seem to be LAB species or strain specific. Up to now, only few studies have focused on characterizing the ACE inhibitory peptides that are derived from foods fermented with $L$. casei, even though the ACE inhibitory activity of this species has previously been described (Pihlanto et al., 2010; Ong et al., 2007).

In the dairy industry, milk heat treatment (e.g., pasteurization) is a commonly employed practice that inactivates undesirable enzyme activities so as to extend the product shelf life (Sánchez-Moreno et al., 2006). Thus, the heat stability of potential ACE inhibitors is an important criterion to consider when manufacturing antihypertensive functional dairy products. Both Bütikofer et al. (2008) and Shu et al. (2015) concluded that ACE inhibitory peptides are influenced by the heat treatment procedures. Furthermore, the potential peptides should be able to withstand the gastrointestinal stresses exerted by the host digestive system (Vermeirssen et al., 2004). The stomach is the first organ encountered by the peptides, and has a strong acidic environment and a high level of gastric pepsin. When passing further down the digestive tract, the peptides are possibly cleaved by the pancreatic proteases, including trypsin, elastase, $\alpha$-chymotrypsin, and carboxypeptidases A and $\mathrm{B}$ at a more alkaline $\mathrm{pH}$. Only after the peptides survive all these harsh physiological conditions, they can be absorbed through the intestinal epithelium (Jao et al., 2012). During the process, some bioactive peptides may also be liberated from the native protein by the action of host digestive proteases or enzymes (or both) secreted during microbial fermentation (Pescuma et al., 2011). An interesting observation reported by PihlantoLeppälä et al. (1998) was the identification of 9 ACE inhibitory peptides from commercial fermented milks that had no ACE inhibitory activity before pepsin and trypsin digestion.

Lactic acid bacteria milk fermentation is a complicated process that involves several enzymes, leading to the release of heterogeneous metabolites, and some of these metabolites may possess specific functions (e.g., ACE inhibition, bacterial suppression, and antioxidation). Thus, a powerful tool is needed to identify and isolate these bioactive materials. Metabolomics is an emerging powerful discipline that depicts the comprehensive sample metabolite profile, particularly the spectrum of small molecules $(<1 \mathrm{kDa})$; hence, it is an effective approach in discovering biomarkers in biological systems (Wang et al., 2012). The ultra-high-performance liquid chromatography electron spray ionization coupled with time-of-flight mass spectrometry (UPLC/ESI-QTOF/MS) has become one of the most important and widely applied tools for metabolomics-based analysis due to its high sensitivity and reproducibility. In addition, various multivariate data analysis methods, including principal component analysis (PCA) and partial least squares discriminant analysis (PLS-DA), have been developed to facilitate the identification of differential abundant bioactive peptides (Chen et al., 2015).

The present study aimed to identify $L$. casei strains that have antihypertensive potential and characterize the strain-specific peptides responsible for such activity. First, we analyzed the ACE inhibitory activity of fermented milks produced with $41 \mathrm{~L}$. casei strains. Second, we evaluated the stability of the ACE inhibitory activity produced by the selected strains under specific treatments of heat and gastrointestinal enzymes. Third, we determined the optimal fermentation conditions (i.e., fermentation temperature, initial inoculum density, and fermentation time) required for producing fermented milk with strong ACE inhibitory activity. Finally, by a metabolomics-based approach, we identified potential ACE inhibitory peptides in L. casei fermented milk. Our work has exploited novel bacterial resources for 
future development of antihypertensive functional dairy foods, which is of interest to the dairy industry.

\section{MATERIALS AND METHODS}

\section{Lactobacillus casei Strains}

The 41 L. casei strains were preserved as freeze-dried powder and deposited at the Lactic Acid Bacteria Culture Collection (Inner Mongolia Agricultural University, China). They were isolated from traditional fermented foods collected from Tibet (13 strains), Inner Mongolia (23 strains), Sichuan (2 strains), Gansu (2 strains), and Mongolia (1 strain). These strains were identified as L. casei by a combination of traditional physiological and biochemical identification methods, together with $16 \mathrm{~S}$ rRNA gene sequence analysis as published previously (Zhang et al., 2012). The strain-specific information and milk fermentation characteristics are shown in Supplemental Table S1 (https://doi.org/10.3168/jds .2017-12970).

\section{Preparation of Fermented Milks}

The $L$. casei strains were activated and grown overnight in reconstituted skim milk at $37^{\circ} \mathrm{C}$, followed by a second transfer to de Man, Rogosa, and Sharpe broth, and incubated at $37^{\circ} \mathrm{C}$ for $18 \mathrm{~h}$. The starter cultures for fermentation were prepared by washing the cells twice with phosphate buffer solution. The reconstituted milk was prepared by suspending $11 \%$ (wt/wt) skim milk powder (NZMP Ltd., Wellington, New Zealand) in sterilized distilled water and heated at $121^{\circ} \mathrm{C}$ for 7 min. Each strain was separately inoculated in a sterile culture flask containing reconstituted skim milk (pasteurized at $95^{\circ} \mathrm{C}$ for $10 \mathrm{~min}$ ) at $2 \%$ concentration. Inoculated skim milk cultures were incubated at $37^{\circ} \mathrm{C}$ for $24 \mathrm{~h}$ before being rapidly cooled in ice water.

\section{Determination of Physical Parameters of Fermented Milks}

The titratable acidity $\left(\mathbf{T A},{ }^{\circ} \mathrm{T}\right)$ and $\mathrm{pH}$ value of the fermented milks were determined based on the standard methods described by the Association of Official Analytical Chemists (method no. 947.05; AOAC, 1990). The bacterial growth was assessed by measuring the optical density at $600 \mathrm{~nm}\left(\mathbf{O D}_{600}\right)$ using a spectrophotometer (UV-1700, Shimadzu, Kyoto, Japan). To determine the ACE inhibitory activity, VPP and IPP peptide concentrations, and free amino nitrogen (FAN) content (assayed by the method described in Church et al., 1983), the fermented milk samples were centrifuged at $6,000 \times g$ for $10 \mathrm{~min}$ at $4^{\circ} \mathrm{C}$. The supernatants were collected for subsequent assays. Unused supernatants were stored at $-20^{\circ} \mathrm{C}$ until further analyses.

\section{Determination of ACE Inhibitory Activity}

The ACE inhibitory activity was measured using the method described by Cushman and Cheung. (1971). Briefly, hippuryl-L-histidyl-L-leucine (HHL) and ACE (Sigma Chemical Co., St. Louis, MO) were separately dissolved in $100 \mathrm{mM}$ Na-borate buffer (pH 8.3) containing $300 \mathrm{mM} \mathrm{NaCl}$. This experiment was carried out by incubating a mixture of $50 \mu \mathrm{L}$ of HHL $(10 \mathrm{mM})$ solution and $50 \mu \mathrm{L}$ of milk supernatant at $37^{\circ} \mathrm{C}$ for 2 min. Then, $50 \mu \mathrm{L}$ of ACE $(0.010 \mathrm{U} / \mathrm{mL})$ solution was added, and the mixture was further incubated at $37^{\circ} \mathrm{C}$ for $30 \mathrm{~min}$. Afterward, the reaction was stopped by heating the mixture in $85^{\circ} \mathrm{C}$ water bath for $10 \mathrm{~min}$ to inactivate the enzyme. Finally, $150 \mu \mathrm{L}$ of deionized water was added; then, $20 \mu \mathrm{L}$ of this solution was directly injected into an HPLC with a Zorbax $\mathrm{C}_{18}$ column (4.6 $\times 250 \mathrm{~mm}$, particle size $5 \mu \mathrm{m}$, Agilent Technologies, Santa Clara, CA) to detect the content of hippuric acid decomposed from HHL. The column was eluted with $75 \%$ acetonitrile (Sigma Chemical Co.) in water (vol/ vol) containing $0.1 \%$ trifluoroacetic acid at a flow rate of $1.5 \mathrm{~mL} / \mathrm{min}$. The eluent was monitored at $228 \mathrm{~nm}$. The column temperature was controlled at $30^{\circ} \mathrm{C}$.

The ACE inhibition activity was calculated by using the following equation:

$$
\begin{aligned}
& \text { ACE inhibitory activity }(\%)= \\
& {[(\mathrm{Cc}-\mathrm{Cs}) /(\mathrm{Cc}-\mathrm{Cb})] \times 100 \%,}
\end{aligned}
$$

where $\mathrm{Cc}, \mathrm{Cb}$, and $\mathrm{Cs}$ were the concentrations of hippuric acid in the control group (without the tested sample), the blank group (without ACE), and the experimental group [with both ACE and the tested sample (sample, Cs)], respectively.

\section{Heat Treatment of L. casei Fermented Milks}

To test the heat tolerance of the ACE inhibitory activity of the fermented milk samples, each sample was heat treated under 3 different conditions $\left(63^{\circ} \mathrm{C}\right.$ for 30 min, $75^{\circ} \mathrm{C}$ for $25 \mathrm{~s}$, and $85^{\circ} \mathrm{C}$ for $20 \mathrm{~s}$ ). After the heat treatment, samples were immediately cooled to $4^{\circ} \mathrm{C}$ in an ice bath, and the $\mathrm{pH}$ of the cooled samples was adjusted to 8.3. The ACE inhibitory activity of each sample was then measured.

\section{Protease Digestion of L. casei Fermented Milks}

To assess the resistance of the fermented milk ACE inhibitory activity to gastrointestinal proteases, the 
samples were digested alone with pepsin $(1: 10,000$, Sigma Chemical Co.), trypsin (1:250, Sigma Chemical Co.), or sequentially with pepsin followed by trypsinase. For pepsin digestion, the fermented milk supernatants $(1 \mathrm{~mL})$ were adjusted to $\mathrm{pH} 2.5$ using $3 \mathrm{~mol} / \mathrm{L}$ of $\mathrm{H}_{2} \mathrm{SO}_{4}$ before adding $20 \mu \mathrm{L}$ of pepsin $(21,000 \mathrm{U} / \mathrm{mL})$. The mixtures were incubated at $37^{\circ} \mathrm{C}$ for $4 \mathrm{~h}$ before heat inactivation $\left(90^{\circ} \mathrm{C}\right.$ for $\left.10 \mathrm{~min}\right)$. For trypsinase digestion, the supernatants were adjusted to $\mathrm{pH} 8.0$ with $0.5 \mathrm{~mol} / \mathrm{L}$ of $\mathrm{NaOH}$ solution, before adding $20 \mu \mathrm{L}$ of trypsinase $(2,500 \mathrm{U} / \mathrm{mL})$. The mixtures were incubated at $37^{\circ} \mathrm{C}$ for $4 \mathrm{~h}$ before heat inactivation. For the sequential pepsin/trypsinase digestion, samples were digested stepwise with pepsin followed by trypsinase digestion according to the conditions and procedures described above. The ACE inhibitory activity of the treated samples was then assayed.

\section{Quantification of VPP and IPP Peptides by UPLC/ESI-Q-TOF/MS}

The VPP and IPP peptide standards (both with a greater than $99.5 \%$ purity level) were purchased from GL Biochem Ltd. (Shanghai, China). The VPP and IPP peptides in the fermented milk samples were determined using the UPLC/ESI-MS system (Waters USA, Milford, MA) connected to a quadrupole time-of-flight instrument (Waters, Manchester, UK). The column was equipped with a $2.1 \mathrm{~mm} \times 100 \mathrm{~mm}$ BEH- $\mathrm{C}_{18}$ column (Waters USA). The injection volume was $4 \mu \mathrm{L}$. Solvent $\mathrm{A}$ and solvent $\mathrm{B}$ were the mixture of water-formic acid (100:0.1, vol/vol) and acetonitrile-formic acid solution (100:0.1, vol/vol). Peptides were eluted with a linear gradient of solvent $\mathrm{B}$ in solvent $\mathrm{A}$ elevating from 5 to $30 \%$ over $5 \mathrm{~min}$ at a flow rate of $0.4 \mathrm{~mL} / \mathrm{min}$.

Data were acquired from the mass-to-charge $(\mathrm{m} / \mathrm{z})$ range of 100 to 700 , using a desolvation temperature of $350^{\circ} \mathrm{C}$, source temperature of $100^{\circ} \mathrm{C}$, cone voltage of $30 \mathrm{~V}$, and collision energy of $6 \mathrm{eV}$. The nitrogen desolvation and nebulizer gas flow rates were set to 600 and $50 \mathrm{~L} / \mathrm{h}$, respectively. The mass spectrometer was calibrated across the $m / z$ range of 100 to 1,500 using a solution of sodium formate. Data were centroided during acquisition using an external reference composed of a $2 \mathrm{ng} / \mathrm{mL}$ solution of Leu-enkephalin infused at $10 \mu \mathrm{L} /$ min, generating an $\left[\mathrm{M}^{+\mathrm{H}}\right]$ at $m / z 556.2771$.

\section{Effects of Fermentation Temperature, Inoculum Concentration, and Fermentation Time}

To assess the effect of temperature on the milk fermentation, $1 \times 10^{6} \mathrm{cfu} / \mathrm{g} \mathrm{L}$. casei seed culture was inoculated into the pasteurized skim milk. The inoculated cultures were fermented at 33,37 , and $40^{\circ} \mathrm{C}$, re- spectively, until the content reached $\mathrm{pH}$ 4.5. The ACE inhibitory activity, and VPP and IPP peptide concentrations were measured.

To test the effect of inoculum concentration on milk fermentation, L. casei seed cultures of 3 different densities, $1 \times 10^{6}, 5 \times 10^{6}$, and $1 \times 10^{7} \mathrm{cfu} / \mathrm{g}$, were inoculated into pasteurized skim milk. Inoculated cultures were fermented at $40^{\circ} \mathrm{C}$ until $\mathrm{pH}$ 4.5. The ACE inhibitory activity was measured.

To identify the optimal fermentation time that was required for achieving a high ACE inhibitory activity, the milk was fermented with a seed culture (inoculum concentration of $1 \times 10^{6} \mathrm{cfu} / \mathrm{g}$ ) at $37^{\circ} \mathrm{C}$. The $\mathrm{pH}$ value, TA, FAN content, $\mathrm{OD}_{600}$, and ACE inhibitory activity of the fermented milks were monitored at various time points during fermentation.

\section{Metabolic Profiling by UPLC/ESI-QTOF/MS Analysis}

The metabolites of L. casei IMAU20411 milk fermentation (over $48 \mathrm{~h}$ ) were analyzed by UPLC/ESIQ-TOF/MS (Waters USA) based on the method described by Zhang et al. (2013). Briefly, a 3-mL sample was centrifuged at $12,000 \times g$ for $10 \mathrm{~min}$ to remove the protein and fat. Then, $12 \mathrm{~mL}$ of acetonitrile was mixed with each sample supernatant. The mixture was filtered through a $0.22-\mu \mathrm{m}$ filter membrane. An aliquot of $5 \mu \mathrm{L}$ of each sample filtrate was injected into an ACQUITY UPLC BEH C18 column $(100 \mathrm{~mm} \times 2.1 \mathrm{~mm}, 1.7 \mu \mathrm{m}$, Waters USA) at $40^{\circ} \mathrm{C}$ at the flow rate of $0.4 \mathrm{~mL} / \mathrm{min}$. The optimal mobile phase was a linear gradient system of solution A ( $0.1 \%$ formic acid in water) and solution B ( $0.1 \%$ formic acid in acetonitrile), 0 to $0.5 \mathrm{~min}, 2 \%$ solution B; 0.5 to $24 \mathrm{~min}$, increased from 2 to $100 \%$ solution B linearly; 24 to $27.5 \mathrm{~min}, 100 \%$ solution B, then decreased to $2 \%$ solution B and kept for 2 min.

Afterward, the eluent was analyzed by a highdefinition mass spectrometer (Waters USA) under the following conditions: the mass spectrometry was in positive ionization mode, the source temperature was $100^{\circ} \mathrm{C}$, the desolvation gas temperature was $350^{\circ} \mathrm{C}$, the cone gas flow was $1 \mathrm{~L} / \mathrm{h}$, the desolvation gas flow was $800 \mathrm{~L} / \mathrm{h}$, the capillary voltage was $3.2 \mathrm{kV}$, the sampling cone voltage was $32 \mathrm{~V}$, the microchannel plate voltage was $2,300 \mathrm{~V}$, and the extraction cone voltage was 3.0 $\mathrm{V}$. The mass spectrometric data were collected over the range of 100 to $1,000(\mathrm{~m} / \mathrm{z})$.

\section{Identification of Differential Abundant Metabolites}

All UPLC/ESI-Q-TOF/MS collected data were analyzed by the Masslynx Application Manager software (V4.1, Waters USA). Specifically, the fragment ion data were extracted and analyzed by the chemically 
intelligent peak-matching algorithms method. Then, the count of each ion was normalized with the total ion count to generate a data matrix consisting of the retention time, $m / z$ value, and normalized peak area $(10,000)$. The multivariate data matrix was analyzed by the EZinfo software 2.8 (Waters USA). Finally, all the variables were mean-centered and Pareto-scaled before unsupervised PCA and PLS-DA. The identification of differential abundant chemical components was based on the results of the PLS-DA loading plot and the Splot of variable importance projection (VIP). A VIP value exceeding 2 was considered significantly different.

The metabolites of interest were identified and confirmed by comparing their mass spectra and chromatographic retention times with the information available in open biochemical databases, such as METLIIN (http://metlin.scripps.edu/), HMDB (http://www .hmdb.ca/), KEGG (http://www.genome.jp/kegg/), and MASSBANK (http://www.massbank.jp/).

\section{Statistical Analysis}

All experiments were performed in triplicate. Statistically significant differences between sample groups were evaluated with ANOVA. Pearson correlation analysis and ANOVA were performed with the SPSS software (version 16, SPSS/IBM, Chicago, IL).

\section{RESULTS}

\section{Physical Properties, ACE Inhibitory Activity, and VPP and IPP Peptide Concentrations}

We first assessed some physical parameters $(\mathrm{pH}, \mathrm{TA}$, $\mathrm{OD}_{600}$, and FAN), the VPP and IPP peptide concentrations, and the ACE inhibitory activity of the fermented milk samples produced with the $41 \mathrm{~L}$. casei strains (Supplemental Table S1; https://doi.org/10.3168/jds .2017-12970). The $\mathrm{pH}$ value and TA of the fermented milk samples greatly varied after $24 \mathrm{~h}$ of fermentation. The $\mathrm{pH}$ value fell between $3.28 \pm 0.01$ and $5.47 \pm 0.24$, whereas the TA was between $44.65 \pm 1.47$ and 253.37 $\pm 2.94^{\circ} \mathrm{T}$, suggesting that the acidification capacity varied between different strains. The bacterial growth and milk protein hydrolysis capacity of the 41 strains were reflected by $\mathrm{OD}_{600}(0.09 \pm 0.02$ to $0.85 \pm 0.00)$ and FAN content $(1.06 \pm 0.10$ to $6.73 \pm 0.47 \mathrm{mmol} / \mathrm{L})$, respectively.

Twenty-two out of the 41 tested fermented milks exhibited relatively high ACE inhibitory activity of over 60\% (Supplemental Table S1; https://doi.org/10.3168/ jds.2017-12970). Particularly, the 2 strains IMAU10408 and IMAU20411 produced fermented milks with the highest ACE inhibitory activity of $73.50 \pm 1.45 \%$ and
$69.79 \pm 0.62 \%$, respectively; thus, they were selected for further characterization. The concentrations of VPP and IPP peptides of the $41 \mathrm{~L}$. casei fermented milk samples ranged from $0.20 \pm 0.03$ to $6.60 \pm 0.25 \mu \mathrm{mol} / \mathrm{L}$ and $0.20 \pm 0.07$ to $5.00 \pm 0.54 \mu \mathrm{mol} / \mathrm{L}$, respectively.

\section{Effect of Heat Treatment and Protease Digestion}

To test the effect of heat treatment on the fermented milk ACE inhibitory activity, samples were treated with 3 commonly used industrial dairy pasteurization conditions (Figure 1a). The ACE inhibitory activity of fermented milks produced with both the IMAU10408 and IMAU20411 strains significantly increased $(P<$ 0.05) after the heat treatment. Especially, the treatment of samples at $65^{\circ} \mathrm{C}$ for 30 min was significantly more effective in enhancing the ACE inhibition (up to $86.41 \pm 0.12 \%$ and $86.00 \pm 0.31 \%$ for IMAU10408 and IMAU20411, respectively) compared with the other 2 tested conditions $(P<0.05)$. Therefore, the treatment at $65^{\circ} \mathrm{C}$ for $30 \mathrm{~min}$ might be the most suitable dairy pasteurization condition for these 2 strains.

We treated the fermented milks with pepsin, trypsinase, and sequential pepsin/trypsinase. All 3 protease treatments significantly enhanced the ACE inhibitory activity $(P<0.05$; Figure $1 \mathrm{~b})$. The ACE inhibitory activity of the L. casei IMAU10408 fermented milk reached $86.41 \pm 0.12 \%$ after pepsin treatment, whereas it increased to $86.62 \pm 0.14 \%$ for the L casei IMAU20411 fermented milk after trypsinase digestion.

\section{Milk Coagulation of L. casei IMAU10408 and IMAU20411}

Short coagulation time is an important criterion for selecting starter bacteria for fermented milk production. Therefore, the coagulation time of L. casei IMAU10408 and IMAU20411 under different fermentation temperatures $\left(33,37\right.$, and $40^{\circ} \mathrm{C}$ ) were compared (Table 1 ). The coagulation time of $L$. casei IMAU20411 was shorter than that of IMAU10408 at 37 and $40^{\circ} \mathrm{C}$. Thus, L. casei IMAU20411 was selected as the candidate for further study.

\section{Influence of Fermentation Temperature and Inoculum Density}

We found that the fermentation temperature used influenced the level of fermented milk ACE inhibitory activity, as well as VPP and IPP contents (Figure 2a). Fermentation at $37^{\circ} \mathrm{C}$ (compared with 33 and $40^{\circ} \mathrm{C}$ ) led to significant increases in the ACE inhibitory activity $(84.84 \pm 1.23 \%)$ and the concentrations of VPP and 

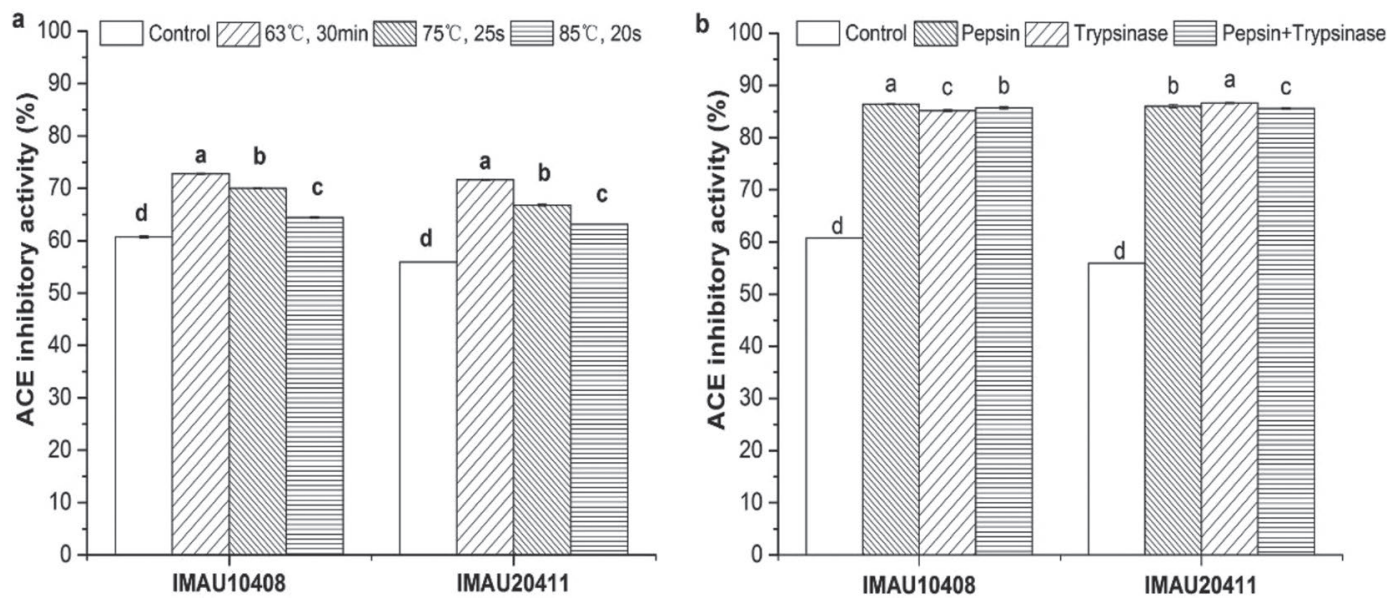

Figure 1. Effects of pasteurization (a) and gastrointestinal protease treatment (b) on the angiotension-converting enzyme (ACE) inhibitory activity of milks fermented by 2 Lactobacillus casei strains. Different letters above the bars represent significant differences in the ACE inhibitory activity between fermented milks produced by the same bacterial strain under specific conditions $(P<0.05)$. Error bars represent SD.

IPP peptides $(1.67 \pm 0.06$ and $1.49 \pm 0.05 \mu \mathrm{mol} / \mathrm{L}$, respectively) in the L. casei IMAU20411 fermented milk.

In addition, our results showed that the initial inoculum density of $L$. casei IMAU20411 affected the level of fermented milk ACE inhibitory activity (Figure 2b). Interestingly, as the initial inoculum increased from 1 $\times 10^{6}$ to $1 \times 10^{7} \mathrm{cfu} / \mathrm{g}$, the ACE inhibitory activity of fermented milks decreased significantly from $55.51 \pm$ $3.04 \%$ to $50.84 \pm 2.22 \%(P<0.05)$.

\section{Monitoring of Physical Parameters and ACE Inhibitory Activity}

Changes in some fermentation characteristics (namely $\mathrm{pH}$, TA, FAN content, and $\mathrm{OD}_{600}$ ) during $L$. casei IMAU20411 milk fermentation were monitored (Figure 3). During the logarithmic phase (4-18 h), the bacterial cells grew exponentially. As the fermentation continued, organic acids were produced and accumulated in the growth medium, leading to the increase in $\mathrm{TA}$, reaching a maximum of $210.69 \pm 12.05^{\circ} \mathrm{T}$ at the fermentation end point $(48 \mathrm{~h})$. In contrast, the $\mathrm{pH}$ value decreased gradually and remained stable after 18 $\mathrm{h}$ of fermentation. It finally reached $\mathrm{pH} 3.52$ after 48

Table 1. The coagulation time (h) of 2 selected Lactobacillus casei strains at different temperatures ${ }^{1}$

\begin{tabular}{llll}
\hline Strain & $33^{\circ} \mathrm{C}$ & $37^{\circ} \mathrm{C}$ & $40^{\circ} \mathrm{C}$ \\
\hline IMAU10408 & 17.50 & 17.00 & 16.50 \\
IMAU20411 & 25.17 & 16.17 & 11.33
\end{tabular}

${ }^{1}$ The coagulation time is the time required for the fermented milk to reach $\mathrm{pH} 4.5$. $\mathrm{h}$ of fermentation. During the first $8 \mathrm{~h}$ of fermentation, the FAN in the growth medium increased from 0 to $6.93 \pm 0.44 \mathrm{mmol} / \mathrm{L}$. After that, the FAN content level fluctuated between $6.65 \pm 0.54$ to $8.31 \pm 1.05$ $\mathrm{mmol} / \mathrm{L}$ until the fermentation ended. In addition, the FAN content of IMAU20411 fermented milk (6.73 \pm $0.47 \mathrm{mmol} / \mathrm{L})$ was significantly higher $(P<0.05)$ than that produced with the other tested strains (ranging from $1.02 \pm 0.12$ to $5.77 \pm 0.14 \mathrm{mmol} / \mathrm{L}$ ) after $24 \mathrm{~h}$ of fermentation (Supplemental Table S1; https://doi.org/ 10.3168/jds.2017-12970).

The ACE inhibitory activity during L. casei IMAU20411 milk fermentation was monitored (Figure 3). The ACE inhibitory activity increased rapidly and reached a peak of $68.21 \pm 1.06 \%$ after $12 \mathrm{~h}$ of fermentation. The ACE inhibitory activity correlated significantly with the FAN content, $\mathrm{pH}, \mathrm{OD}_{600}$, and TA during fermentation $(\mathrm{r}=0.754,-0.951,0.869$, and 0.830 , respectively, $P<0.01$ in all 4 cases).

\section{Identification of Differential Abundant Metabolites Released During Milk Fermentation}

To identify the potential ACE inhibitors, the milk metabolite profiles at different fermentation time points were generated by UPLC/ESI-QTOF/MS analysis. The PCA score plot (principal components 1 and 2 accounting for 95.56 and $2.84 \%$ of the total variation, respectively) displays the metabolite profile data sets of fermented milk samples taken at different fermentation time points (in triplicate; Figure 4). Symbols representing fermented milk samples between 0 to $8 \mathrm{~h}$ of fermentation are in the left quadrants of the plot, whereas those representing samples taken after $10 \mathrm{~h}$ 

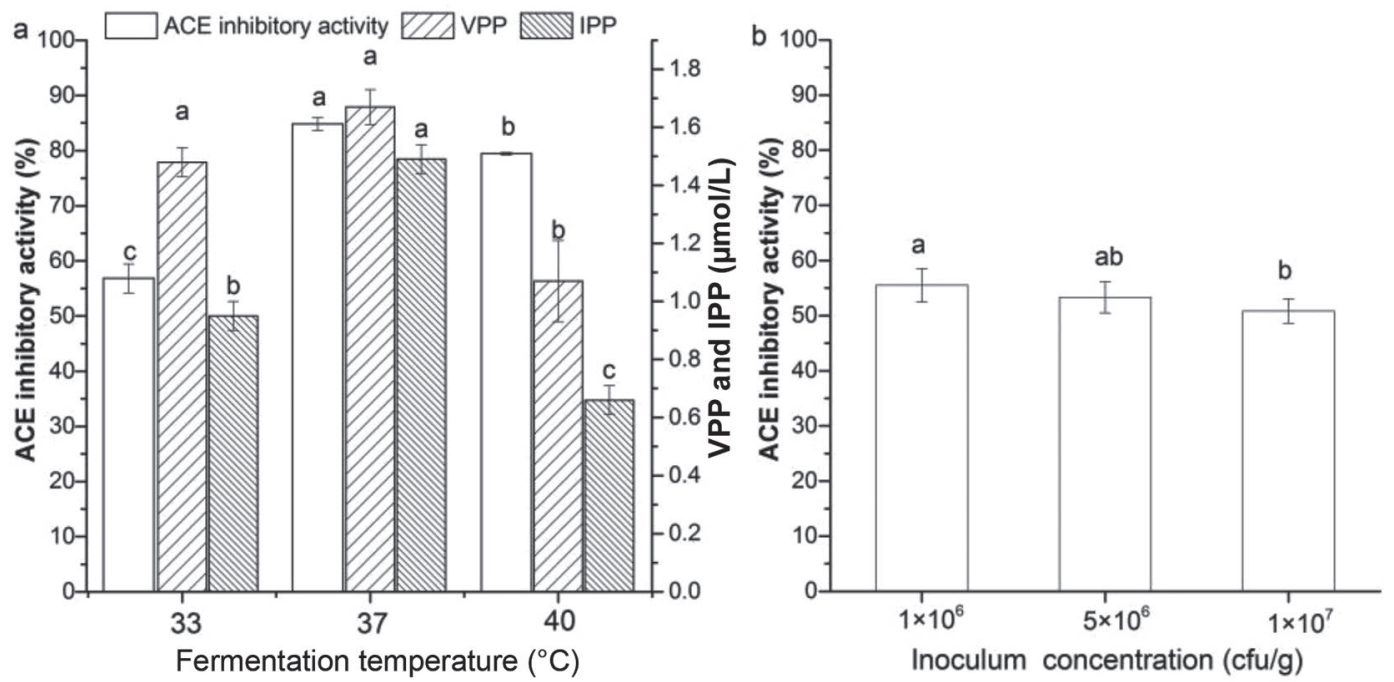

Figure 2. Effects of fermentation temperature (a) and inoculum density (b) on the angiotension-converting enzyme (ACE) inhibitory activity of Lactobacillus casei IMAU20411 fermented milks. Different letters above the bars represent significant differences in the ACE inhibitory activity or peptide concentration between fermented milks produced under different fermentation temperature or inoculum concentration $(P<$ 0.05). Error bars represent SD. VPP = Val-Pro-Pro; IPP = Ile-Pro-Pro.

are in the right quadrants and shift toward the $\mathrm{x}$-axis as the fermentation progressed.

The PLS-DA analysis is a powerful method to identify the differential abundant components existing between metabolomics-based profiles. With PLS-DA, we identified the differential abundant metabolites be- tween samples of 2 and $42 \mathrm{~h}$ of fermentation (Figure 5). The loading plot generated from the UPLC/MS data sets contained a total of 1,074 metabolites. Nine differential abundant peptides (Leu-Ile, Asp-Arg-Glu-Trp, Ala-Lys-Ala-Ala, Glu-Trp-Glu, Phe-Ala-Phe-Ala-Lys, Ala-Glu-Trp, Leu-Gly-Leu, Arg-Thr-His-Tyr, and Leu-

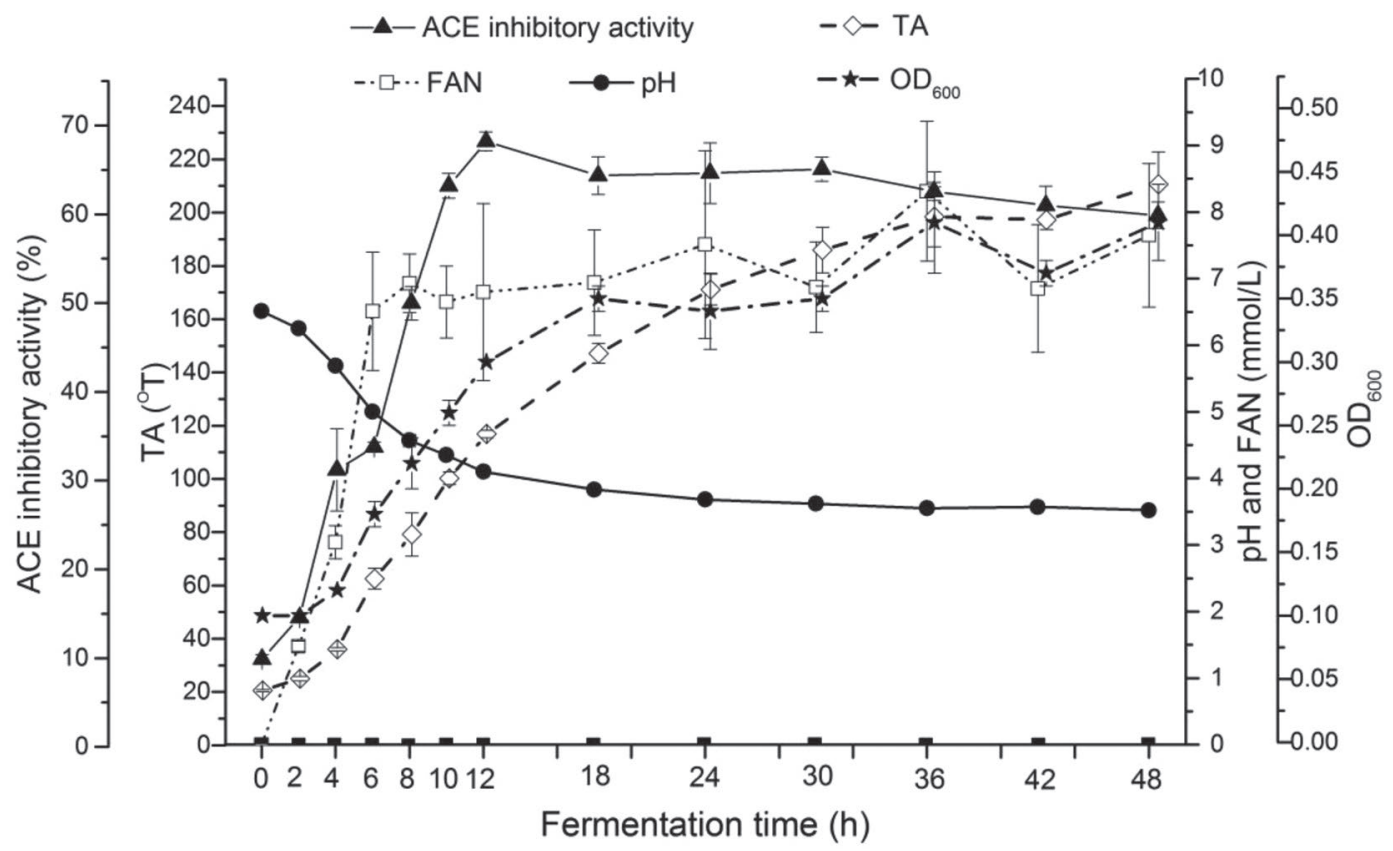

Figure 3. Changes of the angiotension-converting enzyme (ACE) inhibitory activity, titratable acidity (TA), free amino nitrogen (FAN), pH, and absorbance at $600 \mathrm{~nm}\left(\mathrm{OD}_{600}\right)$ during Lactobacillus casei IMAU20411 milk fermentation. Error bars represent SD. 


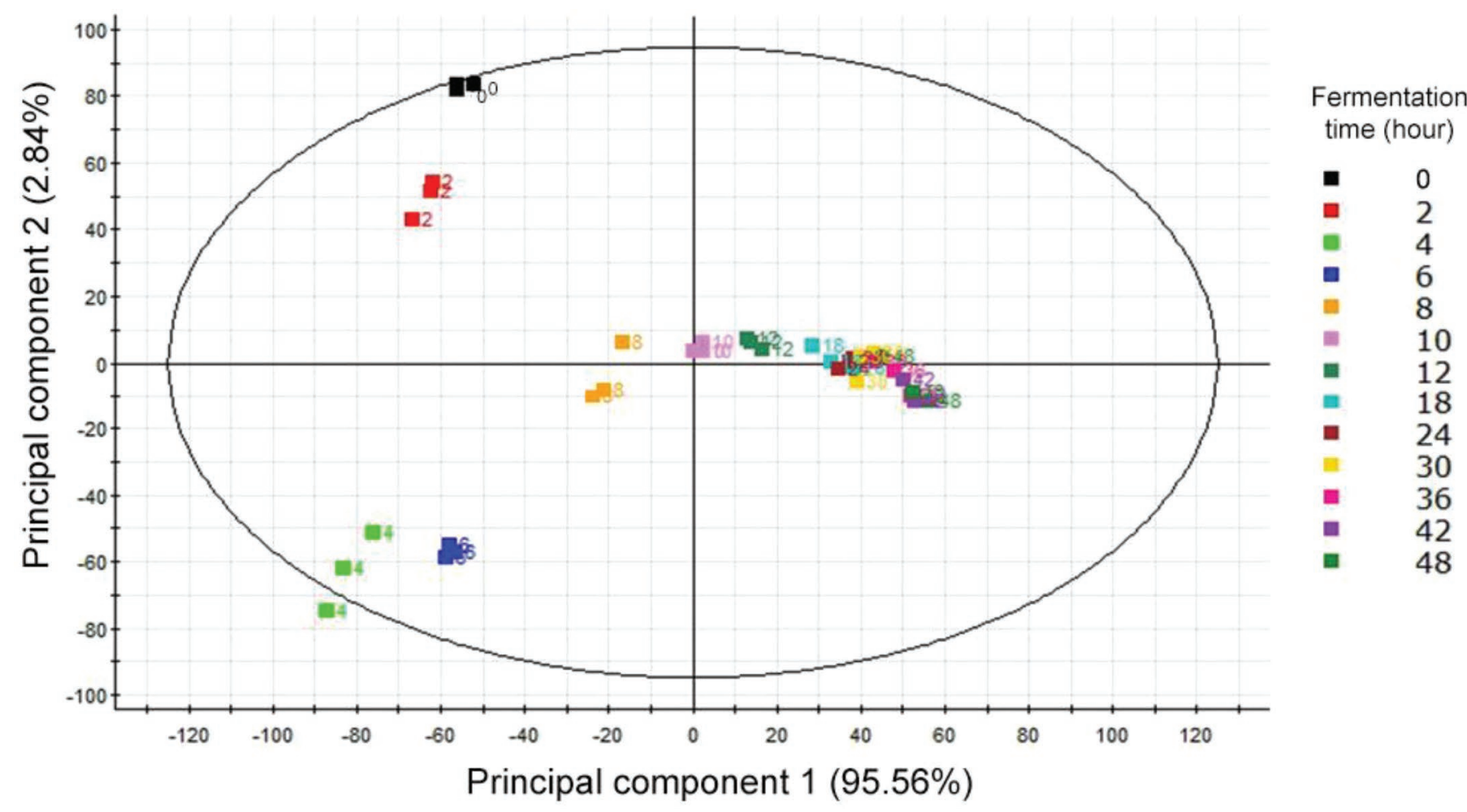

Figure 4. Principal component analysis score plot showing the dynamics of metabolic profiles during fermentation. Triplicate samples were taken for each time point; symbols with different colors correspond to the fermentation time in hours. Color version available online.

Val) were identified between these 2 fermentation time points at a cutoff VIP of 2 (Figure 5). The detailed information of these peptides is shown in Table 2.

Pearson correlation analysis was then carried out to evaluate the relationship between the peptide ion intensity detected by MS and the fermented milk ACE inhibitory activity at different fermentation time points (Figure 6). Interestingly, only 2 peptides (Leu-Ile and Ala-Lys-Ala-Ala) showed a significant positive correlation $(\mathrm{r}=0.822$, and 0.760 , respectively, $P<0.01$ in both cases) with the fermented milk ACE inhibitory effect, suggesting that these 2 peptides might be the key ones conferring such activity. The 2 peptides were first detected after $6 \mathrm{~h}$ of fermentation. Their signal strengths increased during the exponential phase of the bacterial growth (until $18 \mathrm{~h}$ of fermentation) and remained stable afterward (Figure 7 ).

\section{DISCUSSION}

Hypertension is a significant medical condition. Some probiotics bacteria confer an antihypertensive effect to the host via the production of anti-ACE peptides. The species $L$. casei has dual role as an indigenous human gut inhabitant and as starter culture of fermented foods; thus, it carries great potential to be used in functional dairy product development. However, up to now, only a few studies have focused on characterizing the ACE inhibitory activity of $L$. casei.

Our work evaluated the ACE inhibitory capacity of fermented milks produced with $41 \mathrm{~L}$. casei strains. A high proportion of the fermented milks (22 out of 41) showed a high level of ACE inhibitory activity of over $60 \%$. In contrast, Nielsen et al. (2009) tested the ACE inhibitory activity of fermented milks produced with 13 strains, including L. acidophilus, L. helveticus, and Lactococcus lactis, with or without co-fermentation with the species Streptococcus thermophilus; and the ACE inhibitory activity of all the fermented milks was below $60 \%$ (Nielsen et al., 2009). Our results suggest that $L$. casei is a suitable resource to be exploited for anti-ACE capacity. Interestingly, although the VPP and IPP peptides are commonly present in fermented milk products and that their effect of ACE inhibition is well documented (Nakamura et al., 1995; Pihlanto et al., 2010), we found no significant correlation between ACE inhibitory activity and sample peptide concentrations $(P>0.05)$, suggesting that other bioactive ACE inhibitory materials might also be present, which merits further investigation.

To exert beneficial effects on the host's health, the intact bioactive ACE inhibitory components have to 


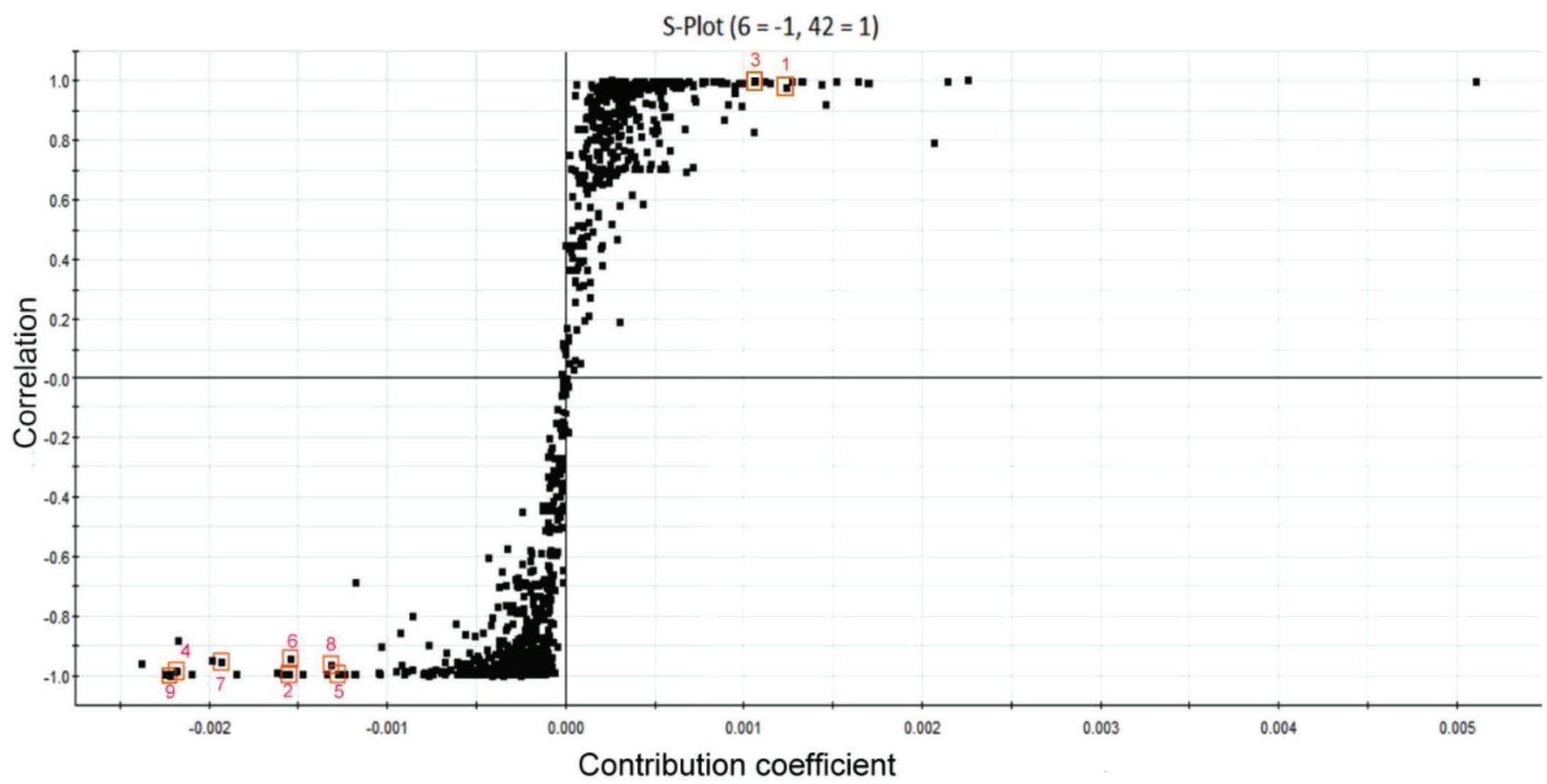

Figure 5. S-plot of partial least squares discriminant analysis of the milk metabolomes after 2 and $42 \mathrm{~h}$ of fermentation. Each dot represents 1 unique metabolite. The 9 significantly different peptides (variable importance projection $>2$ ) between these 2 time points are marked with rectangles. Detailed information on these 9 peptides is shown in Table 2. Color version available online.

Table 2. Differential abundant peptides identified in IMAU20411 fermented milk

\begin{tabular}{|c|c|c|c|c|c|c|}
\hline No. ${ }^{1}$ & $\begin{array}{l}\text { Peptide } \\
\text { sequence }\end{array}$ & $\begin{array}{l}\text { Retention } \\
\text { time (min) }\end{array}$ & $\begin{array}{l}\text { Mass-to-charge } \\
\text { ratio }(m / z)\end{array}$ & $\begin{array}{l}\text { VIP }^{2} \\
\text { value }\end{array}$ & $\begin{array}{l}\text { Potential source } \\
\text { of peptide }\end{array}$ & $\begin{array}{l}\text { Similar ACE inhibitory peptides } \\
\text { reported previously }\end{array}$ \\
\hline 1 & Leu-Ile & 7.6045 & 245.1113 & 2.51249 & $\begin{array}{l}\alpha_{\mathrm{S} 1}-\mathrm{CN} \mathrm{f}(4-5), \\
\beta-\mathrm{CN} \mathrm{f}(4-5), \kappa-\mathrm{CN} \\
\mathrm{f}(71-72), \\
\text { and } \beta-\mathrm{LG} \mathrm{f}(17-18)\end{array}$ & Leu-Ile-Tyr (Meisel et al., 2006) \\
\hline 2 & Asp-Arg-Glu-Trp & 7.3042 & 447.2688 & 3.14787 & $\mathrm{NF}^{3}$ & -4 \\
\hline 3 & Ala-Lys-Ala-Ala & 5.7770 & 360.1906 & 2.18348 & NF & $\begin{array}{l}\text { Lys-Ala-Ala-Ala-Ala-Pro (Escudero } \\
\text { et al., 2014); } \\
\text { Lys-Ala-Ala-Ala-Ala-Thr-Pro } \\
\text { (Escudero et al., 2014); } \\
\text { Ile-Ala-Lys (Gómez-Ruiz et al., 2007) }\end{array}$ \\
\hline 4 & Glu-Trp-Glu & 7.3009 & 461.2672 & 4.51266 & NF & - \\
\hline 5 & $\begin{array}{l}\text { Phe-Ala-Phe-Ala- } \\
\text { Lys }\end{array}$ & 7.2958 & 441.3055 & 2.59381 & $\mathrm{NF}$ & - \\
\hline 6 & Ala-Glu-Trp & 0.6441 & 381.0786 & 3.18918 & NF & - \\
\hline 7 & Leu-Gly-Leu & 12.8231 & 302.3051 & 3.58451 & NF & - \\
\hline
\end{tabular}

${ }^{1}$ The 9 differential abundant peptides were identified between 2 and $42 \mathrm{~h}$ of fermentation, with the peptide number corresponding to that shown in Figure 5.

${ }^{2} \mathrm{VIP}=$ variable importance projection.

${ }^{3} \mathrm{NF}=$ peptide sequence did not correspond to any known milk proteins.

${ }^{4}-=$ no angiotensin-converting enzyme (ACE) inhibitory peptide of similar AA sequence was reported previously. 


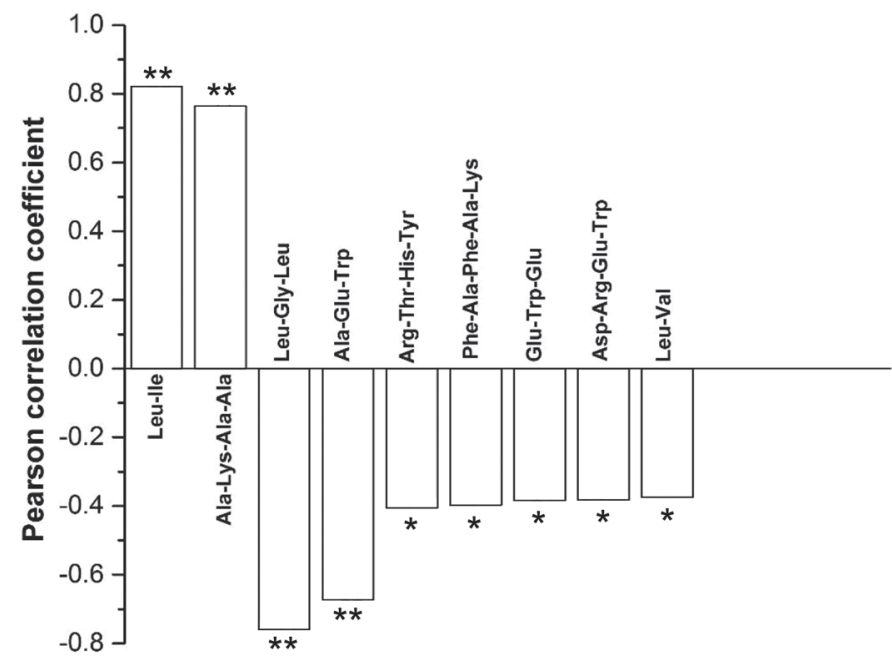

Figure 6. Pearson correlation coefficients between angiotensinconverting enzyme inhibition rate and abundance of 9 fermented milk differential peptides. Samples were taken after $48 \mathrm{~h}$ of fermentation. Asterisks: $0.001<P<0.01$ is represented by ${ }^{* *} ; 0.01<P<0.05$ is represented by $*$.

be absorbed through the intestinal tract. They must also be able to resist the industrial production process (e.g., pasteurization) and survive the harsh conditions within the gastrointestinal tract (e.g., high acidity and protease digestion). Therefore, we tested the heat and protease resistance of the ACE inhibitory activity of the fermented milks produced with 2 selected strains (IMAU10408 and IMAU20411). These 2 strains showed the highest ACE inhibitory activity (Supplemental Table S1; https://doi.org/10.3168/jds.2017-12970).

We found that heat treatment at $65^{\circ} \mathrm{C}$ for $30 \mathrm{~min}$ significant enhanced the ACE inhibitory activity of L. casei fermented milks. Similar findings have been reported in other studies. For example, heat treatment of skim milk at $90^{\circ} \mathrm{C}$ for 30 min and at $135^{\circ} \mathrm{C}$ for $5 \mathrm{~s}$ before fermentation resulted in a 6.5- and 6-fold increase in VPP concentration, respectively (Sieber et al., 2010). Shu et al. (2015) heat treated goat milk at $90^{\circ} \mathrm{C}$ for $5,10,15,20$, or $25 \mathrm{~min}$, and a different degree of enhancement of ACE inhibitory activity was observed, which was correlated with the treatment duration. The enhancement of ACE inhibitory activity was possibly a result of heat-induced protein hydrolysis (Vermeirssen et al., 2004). These results together suggest that product-specific pasteurization conditions should be developed in each case to maximize the ACE inhibitory activity of the final product.

Similarly, in vivo gastrointestinal digestion by hostor microbial-originated proteases may either inactivate the ACE inhibitory materials that are peptide in nature or, alternatively, release the bioactive peptides from the native dietary proteins and hence its bioavailability (Vermeirssen et al., 2003; Vermeirssen et al., 2004; Saavedra et al., 2013). In the digestive system, pepsin cleaves leucine residues and C-terminal aromatic AA, whereas trypsin preferentially attacks positively charged C-terminal AA such as arginine and lysine (Neurath, 1957). Maeno et al. (1996) identified a potent antihypertensive peptide (Lys-Val-Leu-Pro-Val-Pro-Gln), which exhibited a high ACE inhibitory activity only after in vivo digestion, potentially via the action of gastrointestinal enzymes (such as pepsin, trypsin, chymotrypsin, or other peptidases) secreted by the intestinal brush border membranes (Saavedra et al., 2013). Quirós et al. (2009) reported that the ACE inhibitory efficacy of several fermented milk bioactive peptides (namely Leu-His-Leu-Pro-Leu-Pro-Leu, Val-Val-Val-Pro-ProPhe, Leu-Thr-Gln-Thr-Pro-Val-Val-Val-Pro-Pro-Phe, and Val-Arg-Glu-Pro-Phe-Pro-Ile-Ile-Val) increased after incubating with pepsin or pancreatic extracts.

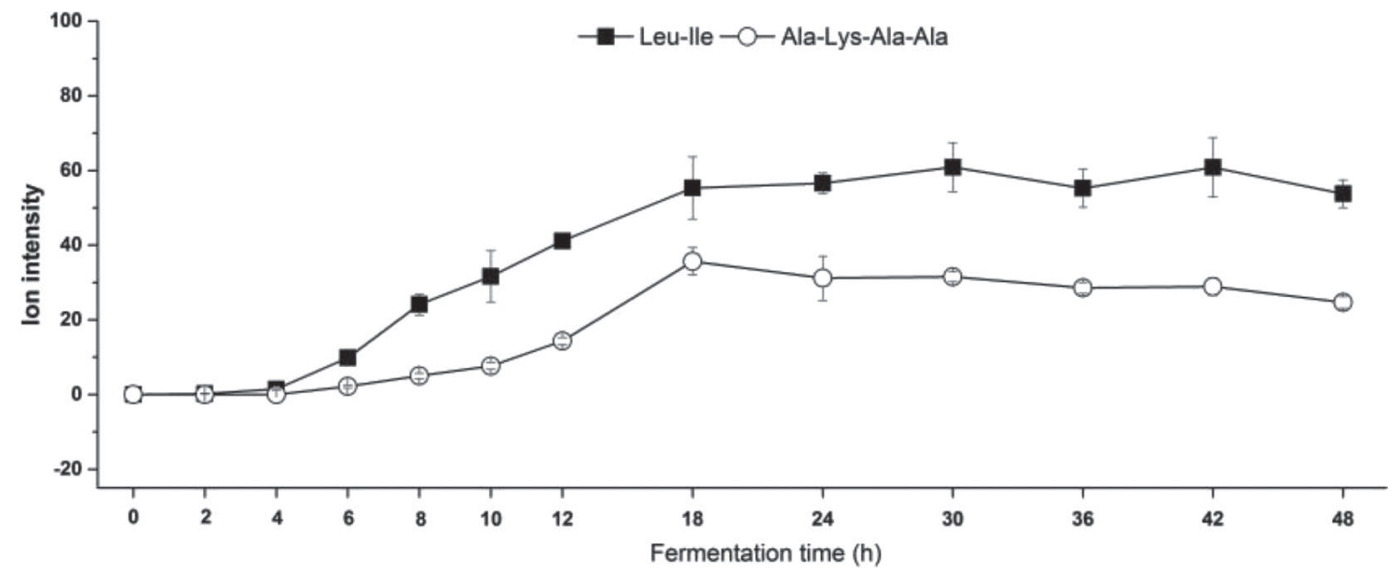
SD.

Figure 7. Changes in the mass spectrometric signal strength of 2 differential abundant peptides during fermentation. Error bars represent 
Moreover, Qureshi et al. (2013) has also shown that the ACE inhibitory activity of cheese increased after simulated gastric or duodenal digestion, or both. In addition, based on the classification of Fujita et al. (2000), some ACE inhibitory peptides in our fermented milk samples may be prodrug-type inhibitors, and they were converted to true ACE inhibitors only after digestion by gastrointestinal proteases. Our results indicate that gastrointestinal digestion is critical in enhancing the bioavailability of ACE inhibitory peptides (Vermeirssen et al., 2003).

The strain L. casei IMAU20411 produced fermented milk with the highest ACE inhibitory activity. Because it has a short coagulation time, it was selected for further optimization experiments. We found that both the initial inoculum density and fermentation temperature affected the level of fermented milk ACE inhibitory activity, which was also observed in similar studies. For example, 35 and $37^{\circ} \mathrm{C}$ were the optimal fermentation temperatures for L. plantarum LP69 and Lactococcus lactis to produce fermented milks of high ACE inhibitory activity (Otte et al., 2011; Shu et al., 2015). Bütikofer et al. (2007) reported that the amounts of cheese antihypertensive peptides (VPP and IPP) were influenced by milk pretreatment and fermentation temperature. The effect of fermentation temperature on ACE inhibitory activity may be explained by an optimal temperature range required by the enzymes responsible for generating the ACE inhibitors. The enzyme X-prolyldipeptidyl aminopeptidase exists naturally in L. casei (Habibi-Najafi and Lee, 1994; Donkor et al., 2007), and the optimal temperature of its hydrolytic activity is $37^{\circ} \mathrm{C}$ (Otte et al., 2011). Another interesting observation is that a higher initial inoculum density may not necessarily be optimal for achieving a high ACE inhibitory activity. This might be due to an excessive acid production followed by a rapid bacterial growth resulting from a dense inoculum. The highly acidic environment could suppress the proteolytic activity required for bioactive peptide generation.

The FAN content was apparently higher in the $L$. casei IMAU20411 fermented milk compared with those produced with other strains (Supplemental Table S1; https://doi.org/10.3168/jds.2017-12970). The FAN content was found to be significantly and positively correlated $(P<0.01)$ with the ACE inhibitory activity. The high FAN level was indicative of a high proteolytic activity of the starter culture (Rasika et al., 2015), and this greatly increased the chance of ACE inhibitory peptide production (Fuglsang et al., 2002). The ACE inhibitory activity gradually decreased until the fermentation ended, possibly due to the depletion of raw materials for peptide production, inhibition of proteases or peptidases by the acidic environment, and the natural degradation of the ACE inhibitory materials. As fermentation progressed, the acidity level increased and correlated with the fermented milk ACE inhibitory activity. This was also observed in milk fermentation of the strains Lactococcus lactis F3 and Lactococcus lactis 3906 (negative correlation with $\mathrm{pH}$ with $\mathrm{r}=-0.53$ and -0.96 , respectively; Otte et al., 2011). The increase in acidity was most likely a result of organic acid accumulation. Meanwhile, more bioactive materials were released during the process.

We then used a metabolomics approach to identify differential abundant metabolites that might be responsible for the ACE inhibition activity. On the PCA plot, symbols representing the early phase of fermentation $(0$ to $12 \mathrm{~h}$ ) were scattered, whereas those representing the later time points (18 to $48 \mathrm{~h}$ ) clustered. The pattern represents the dynamics of the metabolite profile at different fermentation stages. During the exponential cell growth phase, metabolism was vigorous, leading to drastic changes in the metabolite profile. However, when the metabolism slowed down at the later fermentation stage, differences in the metabolite profile between time points narrowed down. The method PLS-DA identifies the differential abundant components between 2 data sets. We used PLS-DA to analyze the metabolite data sets at 2 and $42 \mathrm{~h}$ of fermentation, which represented the initial and the end stages of fermentation, respectively. Although 9 differential abundant peptides were identified based on PLS-DA, only 2 of them (Leu-Ile and Ala-Lys-Ala-Ala) showed positive correlation $(P<$ 0.01 ) with the fermented milk ACE inhibitior activity. Thus, they might be responsible for the observed activity.

The bioactive peptides of dairy products can be released from the milk-originated proteins, including $\alpha-\mathrm{CN}, \beta-\mathrm{CN}, \kappa-\mathrm{CN}$, and whey proteins (e.g., $\alpha-\mathrm{LA}$, $\beta-\mathrm{LG}$, lactoferrin, and immunoglobulins; Fitzgerald and Murray, 2006). The peptide sequence Leu-Ile is common to several milk proteins, including $\alpha-\mathrm{CN}, \beta-\mathrm{CN}, \kappa-\mathrm{CN}$, and $\beta$-LG. However, we failed to identify the source milk protein of the second ACE inhibitory peptide candidate, Ala-Lys-Ala-Ala. We speculate that it might be synthesized and secreted by the starter bacteria. Lactobacillus casei is a ubiquitous microbe that has a remarkable adaptability to different nutritional niches. The representative strain, L. casei ATCC 334, possesses the entire set of enzymes necessary for the biosynthesis of almost all AA (except the branched-chain AA like valine, leucine, and isoleucine; Cai et al., 2009).

Angiotensin-converting enzyme is a transmembrane peptidase, which is bound to the external surface of the cell plasma membrane by a hydrophobic anchor (Murray and FitzGerald, 2007). The ACE inhibitory peptides act as substrates that competitively bind to 
ACE and block its activity (Shori and Baba, 2015). Particularly, the enzyme tends to bind to peptides containing hydrophobic AA residues at each of the 3 positions near the C-terminus (Escudero et al., 2010). Aliphatic (Val, Ile, and Ala), basic (Arg), and aromatic (Tyr and Phe) residues are frequently found at the penultimate C-terminal position in anti-ACE peptides, whereas aromatic (Trp, Tyr, and Phe), proline (Pro), and aliphatic (Ile, Ala, Leu and Met) residues usually locate at the ultimate C-terminal end of peptides (Fujita et al., 2000). The currently identified candidate anti-ACE peptide, Leu-Ile, meets the aforementioned criteria. A previously reported ACE inhibitory peptide, Leu-Ile-Tyr, displays similar sequence characteristics (Meisel et al., 2006). Both candidate peptides identified in this work possess a hydrophobic AA (i.e., Leu, Ile, or Ala) at the C-terminal end, which fulfills the requirement of a strong ACE inhibitory peptide proposed by He et al. (2012). Our second peptide candidate, AlaLys-Ala-Ala, does resemble the AA sequence of several other food-derived peptides that bear the same activity, including Ala-Ala (Cushman, 1981), Lys-Ala-Ala-AlaAla-Pro, and Lys-Ala-Ala-Ala-Ala-Thr-Pro (Escudero et al., 2014).

\section{CONCLUSIONS}

Our study preliminarily evaluated the ACE inhibitory activity of fermented milks produced with $41 \mathrm{~L}$. casei strains. Twenty-two of the fermented milks had a relatively high ACE inhibitory activity of more than $60 \%$. The strain IMAU20411 had the highest ACE inhibitory activity and a short milk coagulation time. Thus, it was chosen for further experiments. An inoculum concentration of $1 \times 10^{6} \mathrm{cfu} / \mathrm{g}$ and the fermentation temperature at $37^{\circ} \mathrm{C}$ were optimal for IMAU20411 to produce fermented milk of a high ACE inhibitory activity. Heat treatment and protease digestion significantly enhanced the ACE inhibitory activity of the fermented milk. Furthermore, by a metabolomics-based approach, we identified 2 potential ACE inhibitory sequences. In short, we identified and characterized the capacity of ACE inhibitory activity of a novel $L$. casei strain, which has potential to be used in future antihypertensive functional dairy food development.

\section{ACKNOWLEDGMENTS}

This research was supported by the National Natural Science Foundation of China (grant no. 31571814). The authors declare no conflicts of interest. Our work does not contain clinical studies or patient data.

\section{REFERENCES}

AOAC. 1990. Official Methods of Analysis. 15th ed. Association of Official Analytical Chemists, Arlington, VA.

Ashar, M. N., and R. Chand. 2004. Fermented milk containing ACEinhibitory peptides reduces blood pressure in middle aged hypertensive subjects. Milchwissenschaft 59:363-366.

Bütikofer, U., J. Meyer, R. Sieber, B. Walther, and D. Wechsler. 2008. Occurrence of the angiotensin-converting enzyme inhibiting tripeptides Val-Pro-Pro and Ile-Pro-Pro in different cheese varieties of Swiss origin. J. Dairy Sci. 91:29-38.

Bütikofer, U., J. Meyer, R. Sieber, and D. Wechsler. 2007. Quantification of the angiotensin-converting enzyme-inhibiting tripeptides Val-Pro-Pro and Ile-Pro-Pro in hard, semi-hard and soft cheeses. Int. Dairy J. 17:968-975.

Cai, H., R. Thompson, M. F. Budinich, J. R. Broadbent, and J. L. Steele. 2009. Genome sequence and comparative genome analysis of Lactobacillus casei: Insights into their niche-associated evolution. Genome Biol. Evol. 1:239-257.

Chen, Y., C. Li, J. Xue, L. Kwok, J. Yang, H. Zhang, and B. Menghe. 2015. Characterization of angiotensin-converting enzyme inhibitory activity of fermented milk produced by Lactobacillus helveticus. J. Dairy Sci. 98:5113-5124.

Church, F. C., H. E. Swaisgood, D. H. Porter, and G. L. Catignani 1983. Spectrophotometric assay using phthaldialdehyde for determination of proteolysis in milk and isolated milk proteins. J. Dairy Sci. 66:1219-1227.

Coates, D. 2003. The angiotensin converting enzyme (ACE). Int. J. Biochem. Cell Biol. 35:769-773.

Cushman, D. W. 1981. Evolution of a new class of antihypertensive drugs. Page 19 in Angiotensin Converting Enzyme Inhibitors: Mechanisms of Action and Clinical Implications. Z. P. Horovitz, ed. Urban \& Schwarzenberg, Baltimore, MD.

Cushman, D. W., and H. S. Cheung. 1971. Spectrometric assay and properties of angiotensin-converting enzyme of rabbit lung. Biochem. Pharmacol. 20:1637-1648.

Domínguez-González, K. N., A. Cruz-Guerrero, H. González-Márquez, L. Gómez-Ruiz, M. García-Garibay, J. Jiménez-Guzmán, and G. Rodríguez-Serrano. 2014. Antihypertensive and antithrombotic activities of a commercial fermented milk product made with Lactobacillus casei Shirota and Streptococcus thermophilus. Int. J. Dairy Technol. 67:358-364.

Donkor, O. N., A. Henriksson, T. Vasiljevic, and N. P. Shah. 2007. Proteolytic activity of dairy lactic acid bacteria and probiotics as determinant of growth and in vitro angiotensin-converting enzyme inhibitory activity in fermented milk. Lait 86:21-38.

Escudero, E., L. Mora, and F. Toldrá. 2014. Stability of ACE inhibitory ham peptides against heat treatment and in vitro digestion. Food Chem. 161:305-311.

Escudero, E., A. M. Sentandreu, K. Arihara, and F. Toldrá. 2010. Angiotensin I-converting enzyme inhibitory peptides generated from in vitro gastrointestinal digestion of pork meat. J. Agric. Food Chem. 58:2895-2901.

Fitzgerald, R. J., and B. A. Murray. 2006. Bioactive peptide and lactic fermentations. Int. J. Dairy Technol. 59:118-125.

Fuglsang, A., D. Nilsson, and N. C. B. Nyborg. 2002. Cardiovascular effects of fermented milk containing angiotensin-converting enzyme inhibitors evaluated in permanently catheterized, spontaneously hypertensive rats. Appl. Environ. Microbiol. 68:3566-3569.

Fujita, H., K. Yokoyama, and M. Yoshikawa. 2000. Classification and antihypertensive activity of angiotensin I-converting enzyme inhibitory peptides derived from food proteins. J. Food Sci. 65:564-569.

Gómez-Ruiz, J. Á., M. Ramos, and I. Recio. 2007. Identification of novel angiotensin converting enzyme-inhibitory peptides from ovine milk proteins by CE-MS and chromatographic techniques. Electrophoresis 28:4202-4211.

Gonzalez-Gonzalez, C. R., K. M. Tuohy, and P. Jauregi. 2011. Production of angiotensin-I-converting enzyme (ACE) inhibitory activity in milk fermented with probiotic strains: Effects of calcium, $\mathrm{pH}$ and peptides on the ACE-inhibitory activity. Int. Dairy J. 21:615-622. 
Habibi-Najafi, M. B., and B. H. Lee. 1994. Purification and characterization of X-prolyl dipeptidyl peptidase from Lactobacillus casei ssp. casei LLG. Appl. Microbiol. Biotechnol. 42:280-286.

He, R., H. Ma, W. Zhao, W. Qu, J. Zhao, L. Luo, and W. Zhu. 2012. Modeling the QSAR of ACE-inhibitory peptides with ANN and its applied illustration. Int. J. Pept. 2012:620609.

Jao, C. L., S. L. Huang, and K. C. Hsu. 2012. Angiotensin I-converting enzyme inhibitory peptides: Inhibition mode, bioavailability, and antihypertensive effects. Biomarkers Med. 2:130-136.

Karakurt, P., and M. K. Kaşikçi. 2012. The effect of education given to patients with type 2 diabetes mellitus on self-care. Int. J. Nurs. Pract. 18:170-179.

Kilpi, E. E. R., M. M. Kahala, J. L. Steele, A. M. Pihlanto, and V. V. Joutsjoki. 2007. Angiotensin I-converting enzyme inhibitory activity in milk fermented by wild-type and peptidase-deletion derivatives of Lactobacillus helveticus CNRZ32. Int. Dairy J. 17:976-984.

Liang, M., and Q. Chen. 2009. Optimization of fermentation conditions of Lactobacillus helveticus for producing milk-derived ACE inhibitory peptides. Food Sci. 31:155-160.

López-Fandiño, R., J. Otte, and J. van. Capm. 2006. Physiological, chemical and technological aspects of milk-protein- derived peptides with antihypertensive and ACE- -inhibitory activity. Int. Dairy J. 16:1227-1293.

Maeno, M., N. Yamamoto, and T. Takano. 1996. Identification of an antihypertensive peptide from casein hydrolysate produced by a proteinase from Lactobacillus helveticus CP790. J. Dairy Sci. 79:1316-1321.

Meisel, H., D. J. Walsh, B. Murray, and R. J. FitzGerald. 2006. ACE inhibitory peptides. Pages 269-315 in Nutraceutical Proteins and Peptides in Health and Disease. Y. Mine and F. Shahidi, ed. CRC Press, Boca Raton, FL.

Murray, B. A., and R. J. FitzGerald. 2007. Angiotensin converting enzyme inhibitory peptides derived from food proteins: Biochemistry, bioactivity and production. Curr. Pharm. Des. 13:773-791.

Nakamura, Y., N. Yamamoto, K. Sakai, and T. Takano. 1995. Antihypertensive effect of sour milk and peptides isolated from it that are inhibitors to angiotensin I-converting enzyme. J. Dairy Sci. $78: 1253-1257$

Neurath, H. 1957. Some considerations of the multiple specificity of proteolytic enzymes. Ann. N. Y. Acad. Sci. 68:11-23.

Nielsen, M. S., T. Martinussen, B. Flambard, K. I. Sørensen, and J. Otte. 2009. Peptide profiles and angiotensin-I converting enzyme inhibitory activity of fermented milk products: Effects of bacterial strain, fermentation $\mathrm{pH}$, and storage time. Int. Dairy J. 19:155-165.

Ong, L., A. Henriksson, and N. P. Shah. 2007. Angiotensin-converting enzyme-inhibitory activity in Cheddar cheeses made with the addition of probiotic Lactobacillus casei sp. Lait 87:149-165.

Otte, J., T. Lenhard, B. Flambard, and K. I. Sørensen. 2011. Influence of fermentation temperature and autolysis on ACE-inhibitory activity and peptide profiles of milk fermented by selected strains of Lactobacillus helveticus and Lactococcus lactis. Int. Dairy J. 21:229-238.

Pescuma, M., E. M. Hébert, H. Rabesona, M. Drouet, Y. Choiset, T. Haertlé, F. Mozzia, G. F. de Valdeza, and J.-M. Chobert. 2011. Proteolytic action of Lactobacillus delbrueckii ssp. bulgaricus CRL 656 reduces antigenic response to bovine $\beta$-lactoglobulin. Food Chem. 127:487-492.

Pihlanto, A., T. Virtanen, and H. Korhonen. 2010. Angiotensin I converting enzyme (ACE) inhibitory activity and antihypertensive effect of fermented milk. Int. Dairy J. 20:3-10.

Pihlanto-Leppälä, A., T. Rokka, and H. Korhonen. 1998. Angiotensin I converting enzyme inhibitory peptides derived from bovine milk proteins. Int. Dairy J. 8:325-331.

Quirós, A., M. M. Contreras, M. Ramos, L. Amigo, and I. Recio. 2009. Stability to gastrointestinal enzymes and structure-activity relationship of $\beta$-casein-peptides with antihypertensive properties. Peptides 30:1848-1853.

Qureshi, T. M., G. E. Vegarud, R. K. Abrahamensen, and S. Skeie. 2013. Angiotensin I converting enzyme inhibitory activity of Norwegian autochthonous cheeses Gamalost and Norvegia after in vitro human gastrointestinal digestion. J. Dairy Sci. 96:838-853.

Rasika, D. M. D., T. Ueda, L. N. Jayakody, L. D. B. Suriyagoda, K. F. S. T. Silva, S. Ando, and J. K. Vidanarachchi. 2015. ACE-inhibitory activity of milk fermented with Saccharomyces cerevisiae K7 and Lactococcus lactis ssp. lactis NBRC 12007. J. Natl. Sci. Found. Sri. Lanka 43:141-151.

Rodríguez-Figueroa, J. C., A. F. González-Córdova, M. J. TorresLlanez, H. S. Garcia, and B. Vallejo-Cordoba. 2012. Novel angiotensin I-converting enzyme inhibitory peptides produced in fermented milk by specific wild Lactococcus lactis strains. J. Dairy Sci. 95:5536-5543.

Saavedra, L., E. M. Hebert, C. Minahk, and P. Ferranti. 2013. An overview of "omic" analytical methods applied in bioactive peptide studies. Int. Food Res. 54:925-934.

Sánchez-Moreno, C., L. Plaza, B. de Ancos, and P. M. Cano. 2006. Impact of high-pressure and traditional thermal processing of tomato purée on carotenoids, vitamin $\mathrm{C}$ and antioxidant activity. J. Sci. Food Agric. 86:171-179.

Shori, A. B., and A. S. Baba. 2015. Fermented milk derives bioactive peptides with antihypertensive effects. Integr. Food Nutr. Metab. 2:178-181.

Shu, G., H. Yang, H. Chen, Q. Zhang, and Y. Tian. 2015. Effect of incubation time, inoculum size, temperature, pasteurization time, goat milk powder and whey powder on ACE inhibitory activity in fermented milk by L. plantarum LP69. Acta Sci. Pol. Technol. Aliment. 14:107-116.

Sieber, R., U. Butikofer, C. Egger, R. Portmann, B. Walther, and D. Weschsler. 2010. ACE inhibitory activity and ACE-inhibiting peptides in different cheese varieties. Dairy Sci. Technol. 90:47-73.

Skeggs, L. T., J. E. Kahn, and N. P. Shumway. 1956. The preparation and function of the angiotensin-converting enzyme. J. Exp. Med. 103:295-299.

Vermeirssen, V., J. V. Camp, and W. Verstraete. 2005. Fractionation of angiotensin I converting enzyme inhibitory activity from pea and whey proteins in vitro gastrointestinal digests. J. Sci. Food Agric. 85:399-405.

Vermeirssen, V., J. Van Camp, K. Decroos, L. Van Wijmelbeke, and W. Verstraete. 2003. The impact of fermentation and in vitro digestion on the formation of angiotensin- I-converting enzyme inhibitory activity from pea and whey protein. J. Dairy Sci. 86:429-438.

Vermeirssen, V., J. Van Camp, and W. Verstraete. 2004. Bioavailability of angiotensin I converting enzyme inhibitory peptides. Br. J. Nutr. 92:357-366

Wang, H. K., C. Dong, Y. F. Chen, L. M. Cui, and H. P. Zhang. 2010. A new probiotic cheddar cheese with high ACE-inhibitory activity and $\gamma$-aminobutyric acid content produced with koumiss-derived Lactobacillus casei Zhang. Food Sci. Biotechnol. 48:62-70.

Wang, X., A. Zhang, Y. Han, P. Wang, H. Sun, G. Song, T. Dong, Y. Yuan, X. Yuan, M. Zhang, N. Xie, H. Zhang, H. Dong, and W. Dong. 2012. Urine metabolomics analysis for biomarker discovery and detection of jaundice syndrome in patients with liver disease. Mol. Cell. Proteomics 11:370-380.

Zhang, A., H. Sun, S. Dou, W. Sun, X. Wu, P. Wang, and X. Wang. 2013. Metabolomics study on the hepatoprotective effect of scoparone using ultra-performance liquid chromatography/electrospray ionization quadruple time-of-flight mass spectrometry. Analyst 138:353-361

Zhang, H. P., Y. F. Chen, W. J. Liu, Z. H. Sun, Q. H. Bao, and W. Y. Zhang. 2012. Biological Diversity of Lactic Acid Bacteria in Natural Fermented Dairy Products. 1st ed. Science Press, Beijing, China. 